\title{
Optimised Design and Analysis of Solar Water Pumping Systems for Pakistani Conditions
}

\author{
Usman Ashraf*, M. Tariq Iqbal \\ Department of Electrical Engineering, Faculty of Engineering and Applied Science, Memorial University of Newfoundland, St. \\ Johns, Canada \\ Email: *uashraf@mun.ca
}

How to cite this paper: Ashraf, U. and Iqbal, M.T. (2020) Optimised Design and Analysis of Solar Water Pumping Systems for Pakistani Conditions. Energy and Power Engineering, 12, 521-542.

https://doi.org/10.4236/epe.2020.1210032

Received: September 4, 2020

Accepted: October 16, 2020

Published: October 19, 2020

Copyright ( 2020 by author(s) and Scientific Research Publishing Inc. This work is licensed under the Creative Commons Attribution International License (CC BY 4.0).

http://creativecommons.org/licenses/by/4.0/ (c) (i) Open Access

\begin{abstract}
This paper is about the optimized design and analysis of two solar water pumping systems in which one of the systems is designed with a battery bank and other with a cylindrical water tank for a selected site in Pakistan. The design, sizing, cost analysis and steady state analysis of the proposed systems were done in HOMER and dynamic analysis of the designed system with battery bank was performed in MATLAB/Simulink. The simulations performed in HOMER involved proper mapping of the loads which helped to evaluate the PV panel requirement, inverter rating, batteries (in case of battery based solution), modeling of water tank as a deferrable load (in case of solution based of water tank) and detailed cost analysis for a life time of 25 years. To verify the design of the solar water pumping system with battery bank, a simulation in MATLAB/Simulink for study of dynamic behavior of the overall system was performed which involved mathematical modeling of a PV panel, buck-boost converter, inverter, battery bank and motor/pump, a perturb and observe maximum power point tracking algorithm based control system. Analysis was conducted based on the economic results that indicate designed solar water pumping system with water tank would be a cheaper solution as compared to solar water pumping system with a battery bank. This work can be taken as a case study for the understanding and optimized designs of solar water pumping system with battery bank and with cylindrical tank in Pakistani conditions.
\end{abstract}

\section{Keywords}

Solar Water Pumping System, MATLAB, Simulink, Solar Energy, HOMER, Manual Formulation Methods, Computers Based Method, Steady State Modeling, Dynamic Modeling, Solar Panels 


\section{Introduction}

Pakistan is primarily an agricultural economy which contributes for about $22.2 \%$ for overall GDP [1] of the country and employs around $42.3 \%$ of the overall country's labour strength [2]. With agriculture being the main stay of economy, an important component of agriculture is water. Pakistan is a country which faces water shortage, with water availability of around $5000 \mathrm{~m}^{3}$ per capita in 1950s. It has shrunk to around $1000 \mathrm{~m}^{3}$ per capita currently [2] and by 2025, the water short fall is expected to reach 150.8 Million acre-foot [3]. Bashir et al. [4] stated the reason for shrinking water resources as poor management of water due to availability of less number of small and large dams for water storage which results in wastage of water.

To combat this shortage of water supply for irrigation, water pumps and tube-wells are installed and since the scenario of electricity in country is not great as a short fall of $5000 \mathrm{MW}$ is faced by the country [5]. So, instead of powering the water pumps through electricity especially in remote areas where there is no or limited access of electricity, fossil fuels have been used to power water pumps. Since Pakistan is a country which is not rich in fossil fuels, increased dependence on imported fossil fuel for the purpose of electricity production has increased the circular debt to 1.2 trillion Pakistani rupees during the time span of last five years [6]. Also with the latest governmental policy shift towards renewable and environment friendly alternative energy sources, reliance on fossil fuels is expected to decrease.

In Pakistan, there is a huge potential for renewable which is around $167.7 \mathrm{GW}$ [5]. In renewable energies, potential for photovoltaics in particular is immense in the country. Pakistan is one of the wealthiest countries in term of its solar potential which is up to $100,000 \mathrm{MW}$ and an average solar insolation for the country is about $5.5 \mathrm{kWh} / \mathrm{m}^{2} /$ day [7].

Keeping in view all the scenarios discussed above, it suggests a direction for implementation of running water pumping systems on renewable sources instead of fossil fuels in Pakistan. The primary reasons are as Pakistan is not a country rich in fossil fuel resources along with its environmental hazards and Pakistan is rich in solar resources which can be tapped to overcome energy requirements for running water pumps.

\section{Literature Review}

Choudhary et al. has discussed evolution [8] of solar water pumping system with time. Throughout the world for some time now due to fluctuating prices of fossil fuel [9] and due to their environmental hazards, there has been huge shift towards Solar water pumping systems and a lot of research and development have been going on in the field of designing and optimisation of a Solar water pumping system. Allouhi et al. has discussed in detail about the solar water pumping systems [10] considering its sizing aspects and economic analysis.

There have been many methods used to design and optimise a solar water 
pumping system. These methods can be classified into two broader categories Manual Formulation Methods and Computer based Methods.

Over the time many manual computation methods have evolved. They are simple and cheap to implement. One such method [11] uses mathematical formulas to calculate photovoltaic panel requirement by considering a fixed tilt angle along with number of batteries required and cost analysis of an overall system over a fixed life cycle. Discussed [12] also many different methods for PV sizing which are based on the loss of load probability (LLP), also a method is discussed which used simple manual computations and require four coefficients to design a stand-alone PV system throughout Spain. In [13] a method is discussed which does PV system curve sizing using a simple procedure which is based upon observed time series of solar radiation and by incorporating simple geometrical concepts in which curve for sizing is constructed, which incorporates data of daily solar insolation.

Computers based method is based on computer simulations but these software are computation intensive. There are two types of analysis which are done using computer based software of a solar water pumping system. One is steady state analysis and other is dynamic analysis of the designed system. In steady state analysis software perform calculations related to sizing of a PV system keeping in view a specific interval of time; they also help to determine the power generated from the source, load mapping and different parameters related to battery and power converter requirements [14]. Many such software for steady state analysis are discussed in [15], few of such software for system sizing are RETScreen [16], PVplanner [17], PVSyst [18], SolarPro [19], SAM (System advisor model) [20], HOMER (Hybrid Optimization Model for Electric Renewables) [21] etc. The other type of analysis of the Solar water pumping system is dynamic analysis which involves analysis and understanding of the subjected system with varying input conditions which normally involve change in irradiance and temperature. Some of the software for dynamic modeling which help to evaluate system with changing conditions of the PV system are TRANSYS (Transient System Simulation Tool) [22], LABVIEW [23], MATLAB [24] etc.

A lot of work is available in literature for conducting steady state analysis of the Solar systems. As we have chosen HOMER for steady state analysis, the work regarding this in the literature is discussed further. Chaichan et al. [25] discussed four different design scenarios for solar water pumping system in Oman using HOMER. Among them three were powered by PV and one system was powered by a diesel generator. After the economical comparison was made cost of energy for diesel generator water pumping system was $0.6092 \mathrm{USD} / \mathrm{kWh}$ which was greater than the cost of energy for the water pumping system which was operated by PV source which was USD $0.4743 / \mathrm{kWh}$. Kazim et al. [26] has done modeling of a solar water pumping for a remote area in Sohar, Oman which can be used for irrigation purposes. For the solar water pumping design he used HOMER and the system requirements for a daily load of $2.22 \mathrm{kWh} /$ day came out to be $12 \mathrm{~V}, 200 \mathrm{Ah}$ four batteries, PV module network of rating of $0.84 \mathrm{~kW}$ and 
an inverter of $0.8 \mathrm{~kW}$ to serve the design purpose. Cost of the system came out to be $0.309 \mathrm{USD} / \mathrm{kWh}$. In this paper [27] four different systems are designed using HOMER for lightning a street in Salalah Oman which is $10 \mathrm{~km}$ long. One system was sourced solely by PV network, second was sourced by wind source only, third system designed was sourced by diesel generator and last was designed using a hybrid approach which used an optimised combination of PV and wind. The hybrid solution of PV and wind proved to be the most cost effective solution which consisted of a wind turbine of $250 \mathrm{~kW}$ and $80 \mathrm{~kW}$ PV panel network backed by 200 (200 Ah/12V) batteries and power converter of $55 \mathrm{~kW}$ size. As per Kammash et al. [28] Renewable energy center at University of technology is to be lighted using PV Panels network, so they used HOMER for the overall system's sizing. The requirement of the PV Panel network came out to be $8 \mathrm{~kW}$, $2012 \mathrm{~V} 200 \mathrm{Ah}$ batteries and a power converter requirement of $4 \mathrm{~kW}$. Initial cost of the overall system came out to be 2000 USD, net cost of the overall system came out to be 32,015 USD and per kWh cost of electricity produced by the system came out to be 0.903 USD. Alkarrami et al. [29] designed a water pumping system for a site in Sirte city Libya, which was sourced by hybrid energy sources. In this he used three different software to design the proposed system namely HOMER Pro, HOMER Beta and iHOGA and as per his analysis HOMER Pro gave the best results. This paper [30] discussed about the design of a PV water pumping system for Bangladeshi conditions which is already in operation in Lalmonirhat, Bangladesh. For PV water pumping system sizing the software used was HOMER. After the analysis the PV Panel requirement came out to be $15.013 \mathrm{~kW}$, battery bank capacity requirement came out to be $2600 \mathrm{Ah}$ and power converter or inverter requirement came out to be $21 \mathrm{~kW}$. The dynamic modeling for the overall system with battery bank, without battery and water tank and a hybrid storage system consisting of small battery bank and a small water tank was done using MATLAB/Simulink.

For dynamic modeling a lot of work is available in literature but the scope of this paper is limited to dynamic modeling in MATLAB/Simulink. In [31] a PV operated multi staged centrifugal pump which was driven by an induction motor was discussed and the pumping system was aided with battery bank for excess energy storage purpose as well. For dynamic behavior evaluation of the overall system MATLAB/Simulink was used and at the end results were compared with manufacturer's data and results were differing by a small margin. In this paper [32] MATLAB/Simulink is used to evaluate the dynamic behavior of a Solar water pumping system with brushless DC motor, it has a zeta converter as DC-DC converter which is used for maximum power extraction during its operation. The simulation results were verified with the manufacturer's data. After simulation, an overall efficiency of $83 \%$ was obtained at solar insolation of $1000 \mathrm{~W} / \mathrm{m}^{2}$ and an overall efficiency of $71 \%$ was obtained at solar insolation of $400 \mathrm{~W} / \mathrm{m}^{2}$. A solar water pumping system is modeled in MATLAB/Simulink [33] and the pumping system is controlled by vector controlled permanent magnet synchronous motor. In MATLAB/Simulink the modeled system was evaluated un- 
der steady or starting state and dynamically changing insolation conditions.

Keeping in view the above literature review, while designing and sizing of a solar water pumping system for this work we chose HOMER for steady state analysis as it gave the most consistent and reliable sizing results and was found to be most widely used software. For dynamic analysis of the designed system MATLAB was chosen because as per literature many results of dynamic analysis from MATLAB were compared with manufacture's data and they found simulation results to be in line with manufacturer's data which not only verified the results but also suggest MATLAB to be a good option for dynamic analysis of the designed solar water pumping system.

Since the MATLAB blocks do not allow large set of data for irradiance and temperature to be processed at a rapid speed as they are more complex and reduce computation speed for analysis of large set of input data. To overcome this issue and make our system simpler to increase computation speed, mathematical modeling of different components of the overall solar water pumping system used in our designed system was done in MATLAB namely PV Panel, MPPT, Buck-Boost Converter, Battery Bank, Inverter and water pump using 3 phase induction motor.

\section{Design of Solar Water Pumping System with Battery Bank in HOMER}

\subsection{Site Selection}

A suitable site was selected where a solar water pumping system can be implemented for that purpose an agricultural area known as "Mustafa Research Farms" which is located at Wasti Jiuan Shah, Tehsil Sadiqabad, Rahim Yar Khan, Pakistan. The coordinates of location are $28^{\circ} 14^{\prime} 24.0^{\prime \prime} \mathrm{N} 69^{\circ} 37^{\prime} 16.0^{\prime \prime E}$ [34]. It covers an area of around 239.6 acres of land. The crop cultivated on this land is Rhodes Grass which is grown for commercial purposes and is exported from Pakistan to many countries of the world.

The Mustafa Research Farms can be seen in Figure 1, is bordered by blue line in the figure and as this whole area is irrigated by five diesel water pumping systems, the location of the water pumping systems can be seen by circles in blue.

\subsection{Solar Insolation Details of the Selected Site}

The solar insolation details along with clearness index can be seen in Figure 2, which is extracted from the database of National Renewable Energy Laboratory [35] as its database is attached with HOMER. From the figure, it can be seen that the GHI (Global Horizontal Index) varies from 3.6 to $7.26 \mathrm{kWh} / \mathrm{m}^{2} /$ day and its clearness index varies in the range of 0.601 to 0.69 .

\subsection{Data Collected from Site}

The data collected from the selected agricultural site for motor/pump load calculation is as follows and the yearly operation of the motor is summarised in Table 1. 


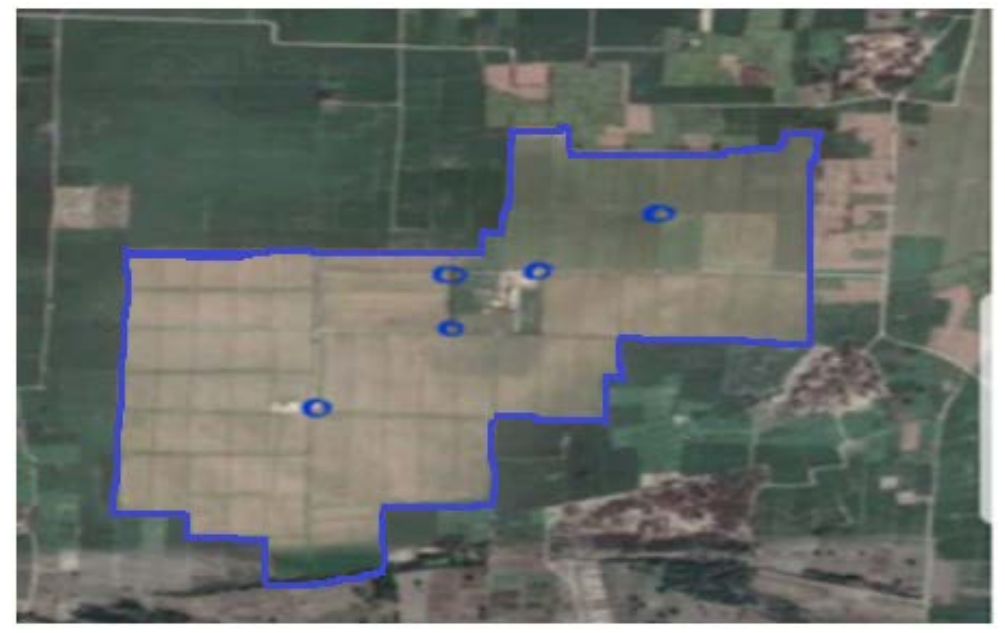

Figure 1. Selected agricultural site "Mustafa Research Farms"; its border can be seen with the blue line drawn and location of the diesel water pumping systems are in blue circle.

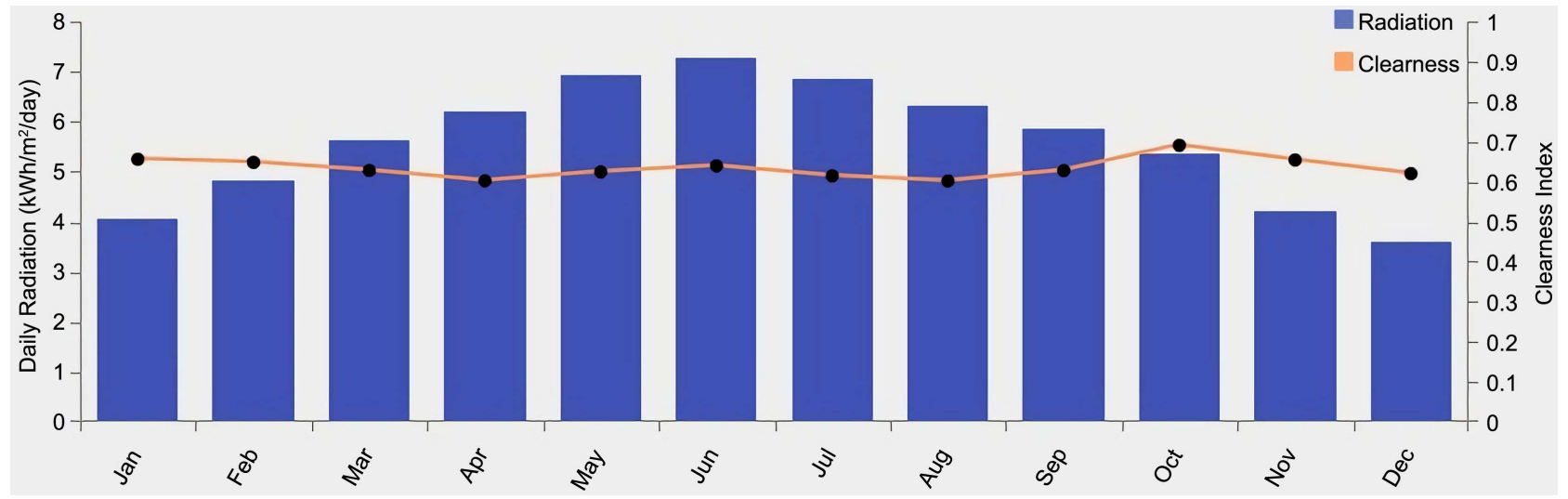

Figure 2. Insolation and clearness index details of selected site.

Table 1. Load profile of the water pumping system.

\begin{tabular}{ccc}
\hline \multirow{2}{*}{$\begin{array}{c}\text { Months } \\
\text { January } \\
\text { February } \\
\text { March }\end{array}$} & Days of full operation $(24 \times 7)$ & Days of idle operation \\
April & First 10 days of the month & Next 24 days of the month \\
May & First 11 days of the month & Next 20 days of the month \\
June & First 14 days of the month & Next 16 days of the month \\
July & First 17 days of the month & Next 14 days of the month \\
August & First 20 days of the month & Next 10 days of the month \\
September & First 22 days of the month & Next 9 days of the month \\
October & First 24 days of the month & Next 7 days of the month \\
November & First 18 days of the month & Next 12 days of the month \\
December & First 14 days of the month & Next 17 days of the month \\
\hline
\end{tabular}


Water level $=25 \mathrm{ft}=7.62 \mathrm{~m}$

Dynamic head $=35 \mathrm{ft}=10.668 \mathrm{~m}$

Water flow requirement $=2$ cusec $($ cubic feet $/ \mathrm{sec})=204 \mathrm{~m}^{3} / \mathrm{hr}=898.2 \mathrm{gpm}$

The brand selected for the water pump/motor is Wilo, it has an online tool [36] that was used to evaluate the motor and pump size. The required data (flow rate and total dynamic head the motor) was incorporated in the online tool, the motor rating came out to be of $11 \mathrm{~kW}$ which is almost equivalent to $15 \mathrm{hp}$. The details regarding the motor/pump can be seen in Figure 3. Details led to the selection of Atmos GIGA-N 125/200-11/4 [37]. The further details regarding motor/pump are summarized in Figure 4.

\section{Motor data}

Mains connection: $3 \sim 400 \mathrm{~V} / 50 \mathrm{~Hz}$

Voltage tolerance: $\pm 10 \%$

Motor efficiency class: IE3

Rated power: $11 \mathrm{~kW}$

Rated speed: 1470 1/min

Rated current: $20.9 \mathrm{~A}$

Power factor: 0.77

Motor efficiency: $91.1 \%$

Motor efficiency: $91.8 \%$

Motor efficiency: $91.6 \%$

Protection class: IP55

Insulation class: $\mathrm{F}$

\section{Installation dimensions}

Pipe connection on the suction side: DN 150 , PN16

Pipe connection on the pressure side: DN 125, PN16

Figure 3. Details of motor/pump for selected site.

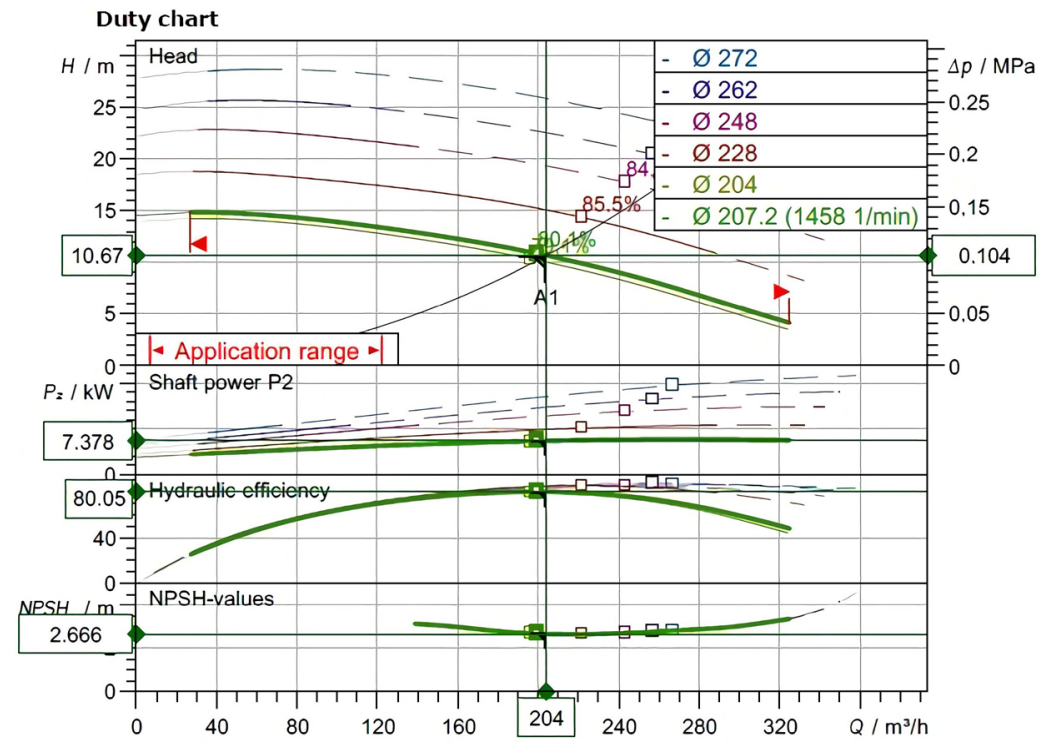

Pump curves in accordance with ISO 9906: 2012 3B

Figure 4. Selection parameters which led to the motor selection.

\section{Requested data}

Flow

Head

Media

Fluid temperature

Density

Kin. viscosity

Hydraulic data (Duty point)

Flow

Head

Shaft power P2

Hydraulic efficiency

NPSH

Impeller size

Product data

Glanded standard pump

Atmos GIGA-N 125/250-11/4

Max. operating pressure

Fluid temperature

Max. ambient temperature

Minimum efficiency index (MEI)

Motordata per Motor/Pump

Motor efficiency level

Mains connection

Permitted voltage tolerance

Max. speed

Rated power P2

Rated current

Power factor
$204.00 \mathrm{~m}^{3} / \mathrm{h}$

$10.67 \mathrm{~m}$

Water $100 \%$

$20.00^{\circ} \mathrm{C}$

$998.20 \mathrm{~kg} / \mathrm{m}^{3}$

$1.00 \mathrm{~mm}^{2} / \mathrm{s}$

$204.00 \mathrm{~m}^{3} / \mathrm{h}$

$10.67 \mathrm{~m}$

$7.38 \mathrm{~kW}$

$80.05 \%$

$2.67 \mathrm{~m}$

207.2

1.6 MPa

$-20^{\circ} \mathrm{C} \ldots+140^{\circ} \mathrm{C}$

$40^{\circ} \mathrm{C}$

$\geq 0.4$

IE3

$3 \sim 400 \mathrm{~V} / 50 \mathrm{~Hz}$

$\pm 10 \%$

$14701 / \mathrm{min}$

$11.00 \mathrm{~kW}$

$20.90 \mathrm{~A}$

0.77 


\subsection{Sizing of the Proposed System Using HOMER}

Now, the next step was to map the load details in HOMER as per the motor operation table summarized in Table 1 and the calculated motor/pump load. Then the simulation in HOMER was performed to get the optimum ratings of different design components of the proposed solar water pumping systems. The diagram of the overall proposed solar water pumping system can be seen in Figure 5.

After the simulation was performed in HOMER, the sizing results which came are summarised in Figure 6. The PV Panel network which is composed of Astronergy ASM6612P-320 solar panel [38], its requirement came out to be $73.8 \mathrm{~kW}$, the battery bank which is composed of Trojan SAGM 12105 [39] requirement

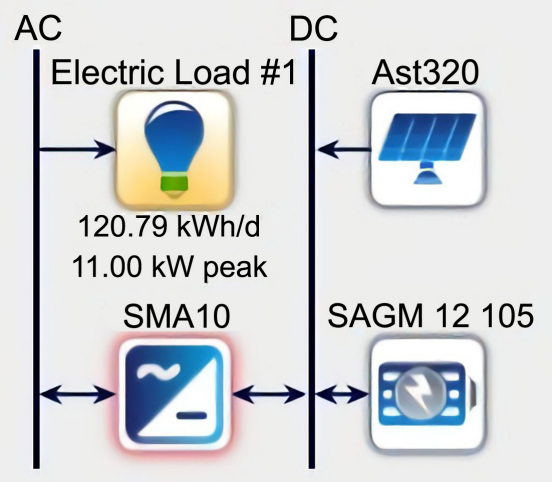

Figure 5. Proposed solar water pumping system with a battery bank.

\section{Simulation Results}

System Architecture:

SMA America STP20000TL-US-10 (480V) (16.7 kW)

Total NPC:

Astronergy Solarmodule320ASM6612P 320 (73.8 kW) HOMER Cycle Charging

Trojan SAGM 12105 (15.0 strings)

SMA America STP20000TL-US-10 (480V) Emissions

Cost Summary Cash Flow Compare Economics Electrical Renewable Penetration Trojan SAGM 12105 Astronergy Solarmodule320ASM6612P 320

\begin{tabular}{|l|c|}
\hline Production & $\mathrm{kWh} / \mathrm{yr}$ \\
\hline Astronergy Solarmodule320ASM6612P 320 & 126,095 \\
\hline Total & 126,095 \\
\hline 4 \\
\hline
\end{tabular}

\begin{tabular}{|l|l|l|}
\hline Consumption & $\mathrm{kWh} / \mathrm{yr}$ & $\%$ \\
\hline AC Primary Load & 44,087 & 100 \\
DC Primary Load & 0 & 0 \\
Deferrable Load & 0 & 0 \\
Total & 44,087 & 100
\end{tabular}

\begin{tabular}{|l|l|l|}
\hline Quantity & $\mathrm{kWh} / \mathrm{yr}$ & $\%$ \\
\hline Excess Electricity & 76,495 & 60.7 \\
Unmet Electric Load & 1.27 & 0.00290 \\
Capacity Shortage & 42.6 & 0.0966 \\
\hline
\end{tabular}

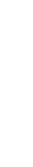

Total $\quad 44,087 \quad 100$

\begin{tabular}{|l|c|l|}
\hline Quantity & Value & Units \\
\hline Renewable Fraction & 100 & $\%$ \\
Max. Renew. Penetration & 614 & $\%$ \\
\hline
\end{tabular}

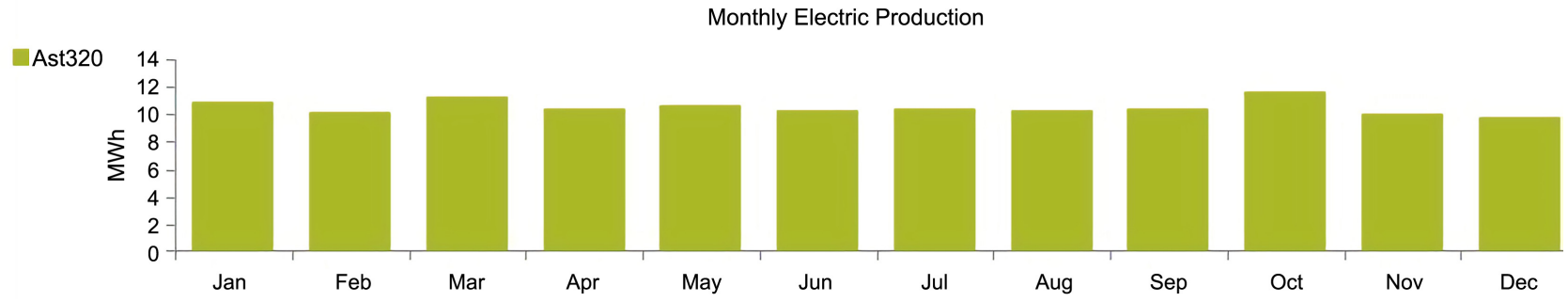

Figure 6. Simulation results for proposed system. 
number came out to be 450 , DC bus voltage $360 \mathrm{~V}$, the inverter requirement came out to be $16.7 \mathrm{~kW}$ and for that purpose an SMA Sunny Tripower 20000TL-30 [40] was incorporated to serve the purpose.

The overall proposed system can be seen in Figure 7. As the PV panel network requirement came out to be $73.8 \mathrm{~kW}$, so a total of $24024 \mathrm{~V}$ panels will be required to fulfill the requirement with 16 panels in series and 16 such strings in parallel, the batteries requirement of 450 is fulfilled by 30 batteries connected in series and 15 such strings connected in parallel. Purpose of having $16 \mathrm{PV}$ panels in series and 30 batteries in series per string is to maintain a dc bus voltage of $360 \mathrm{~V}$. An inverter of $20 \mathrm{~kW}$ is placed.

\subsection{Economic Analysis of the Proposed System Using HOMER}

The economic analysis of the overall proposed system over its life cycle of 25 cycles was also done using HOMER. The cost summary of the overall proposed system is summarised in Figure 8. It can be seen that the total net present cost of

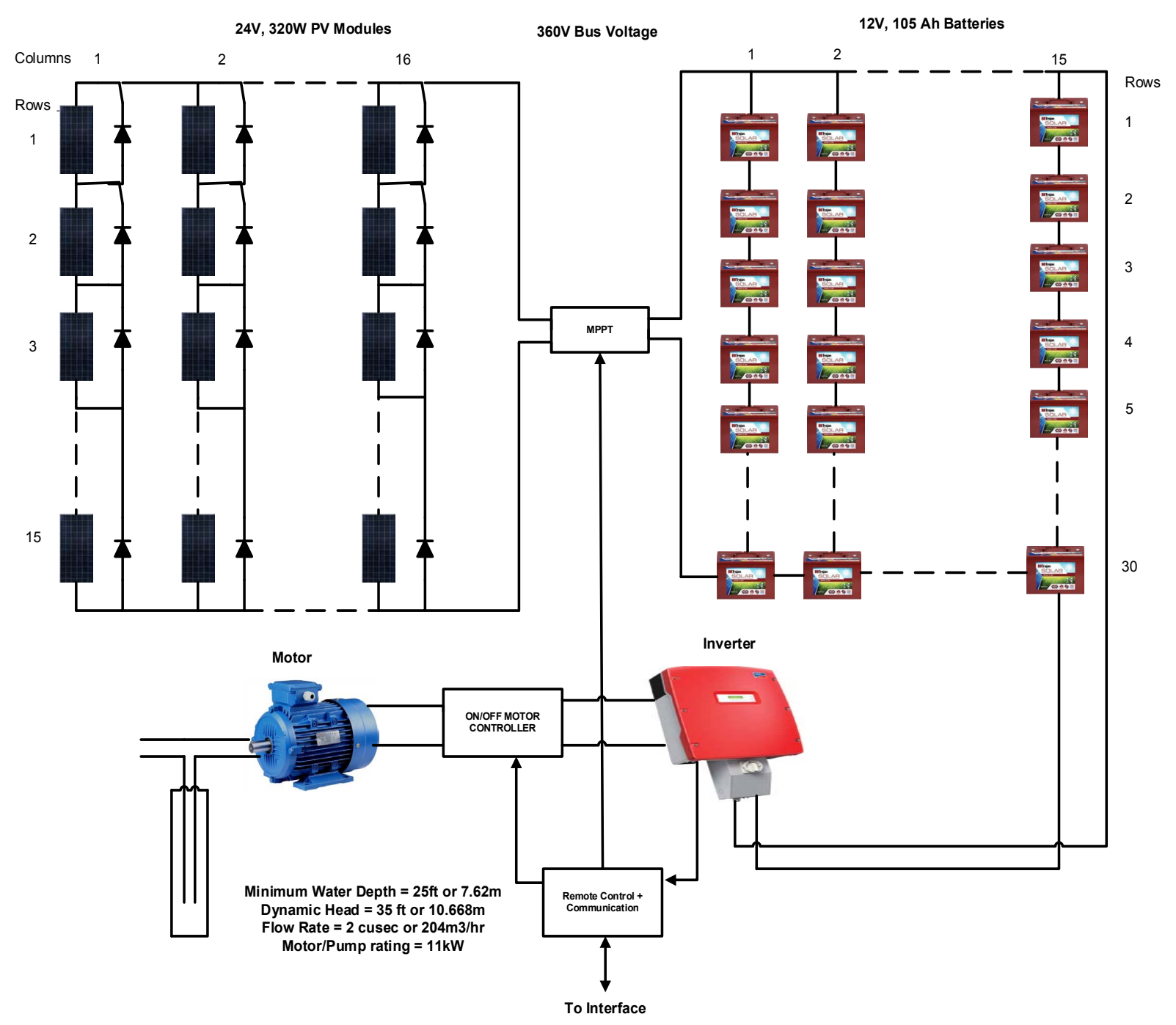

Figure 7. Overall proposed solar water pumping system with battery bank. 


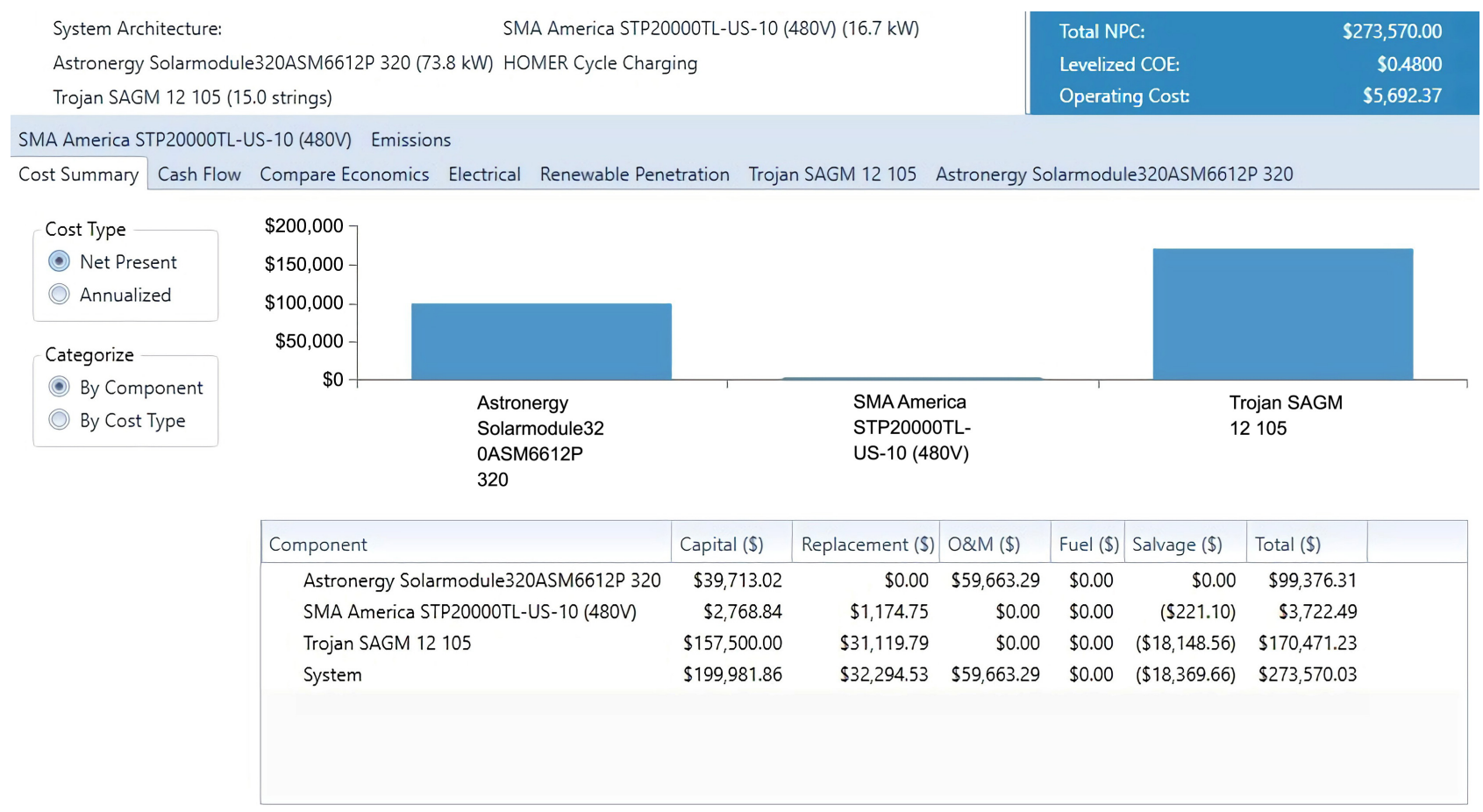

Figure 8. Cost Summary of the proposed system.

the overall system is $\$ 273,570$, the levelized cost of energy of the system comes out to be $\$ 0.48$ along with operating cost which is $\$ 5692.37$ per year.

As per cash flow over the life cycle of 25 years for the proposed system which can be seen in Figure 9. The initial investment which is required is $\$ 199,981.86$, then an annual investment of $\$ 4615.22$ is required from the 1st year of its operation to the 25 th year of its operation. At 21 st year a further investment of $\$ 99,000$ is required to keep the system running. After the end of the cycle of 25 years a salvage value of $\$ 76,681.52$ is available for the overall system.

\section{Verification of Proposed System with Battery Bank Using Dynamic Modeling}

The dynamic modeling of the proposed system was done in MATLAB/Simulink. Mathematical modeling for different design components was done so that speedy simulation with a much overall simplified system can be done. The model of the proposed system can be seen in Figure 10 .

The data was simulated for the first seven days of the April, when the motor is in operation to evaluate the dynamic behavior of the proposed solar water pumping system. The solar data which include solar irradiance and temperature for the first seven days of April which makes it a total simulation for 10,080 minutes can be seen in Figure 11. The irradiance varied from 0 to $1021 \mathrm{~W} / \mathrm{m}^{2}$ and temperature varied from $25^{\circ} \mathrm{C}$ to $49.5^{\circ} \mathrm{C}$ during a week of simulation.

Simulation results are split into two figures (A and B) for the proposed system which can be seen in Figure 12 and Figure 13. It can be seen in Figure 12 that, as far as PV panel output is concerned the output varied throughout the week 
System Architecture:

SMA America STP20000TL-US-10 (480V) (16.7 kW)

Astronergy Solarmodule320ASM6612P 320 (73.8 kW) HOMER Cycle Charging

Trojan SAGM 12105 (15.0 strings)

SMA America STP20000TL-US-10 (480V) Emissions

Cost Summary Cash Flow Compare Economics Electrical Renewable Penetration Trojan SAGM 12105 Astronergy Solarmodule320ASM6612P 320

(-) BarChart () Table

Display: (-) By Cost Type By Component Cash Flow: (a) Nominal Discounted

Replacement $\$ 100,000$

Salvage

Operating

Capital

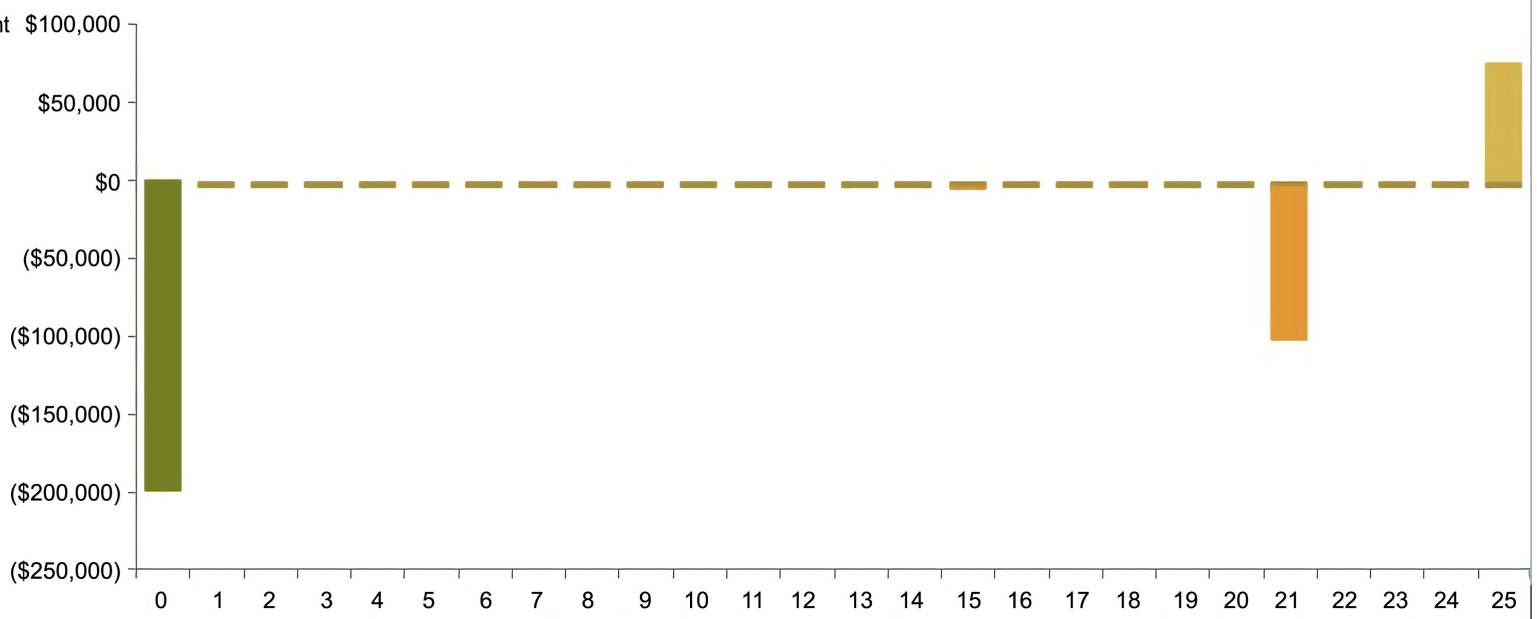

Figure 9. Cash summary of proposed system.

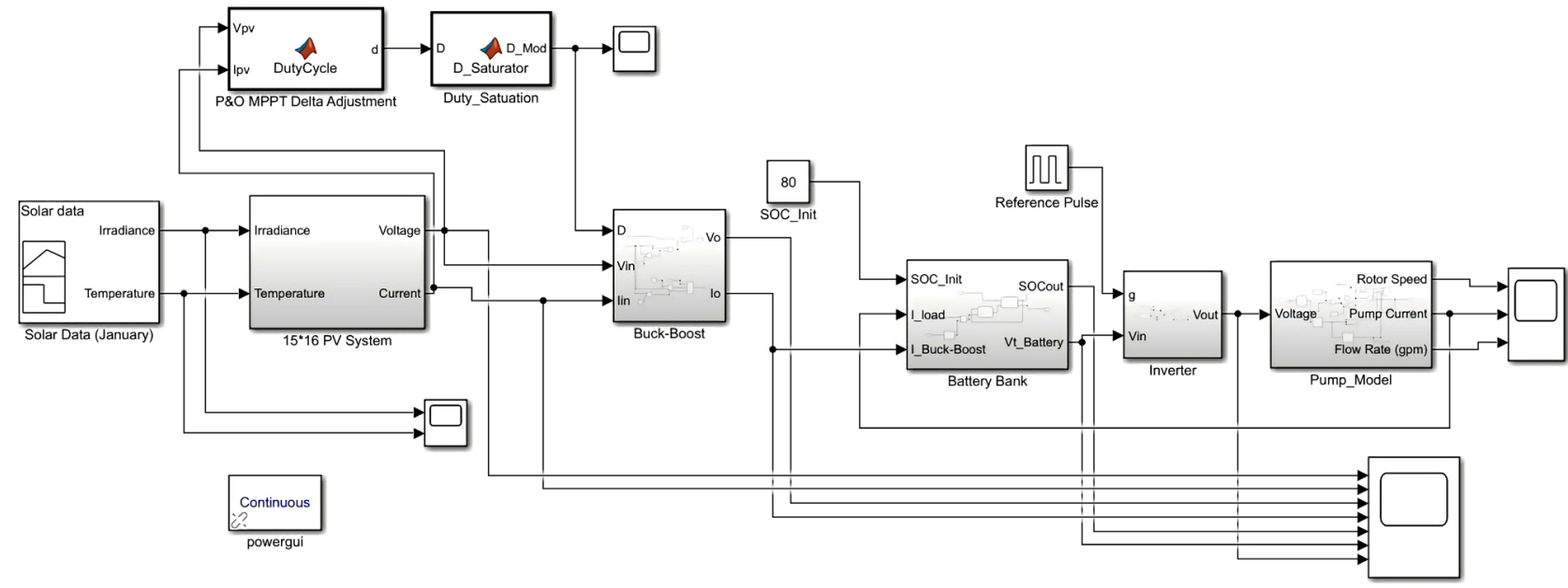

Figure 10. Dynamic model of proposed solar water pumping system with battery bank.

with the varying irradiance and temperature. The voltage output varied from 0 to a maximum of $658 \mathrm{~V}$ and current varied from $130 \mathrm{~A}$ to $0 \mathrm{~A}$. This output in next step is fed to the buck-boost converter which is controlled by the duty cycle which in turn is controlled by Perturb and Observe MPPT technique block. The voltage output from buck-boost converter varies from 0 to $987 \mathrm{~V}$ and current output varied from 0 to $87 \mathrm{~A}$.

The initial SOC (State of charge) of the battery was $80 \%$ which declined to $79 \%$ after 1 st discharge varied between $84 \%$ and $100 \%$ afterwards throughout the simulation as can be seen in Figure 13. The output voltage was only once 377.5 


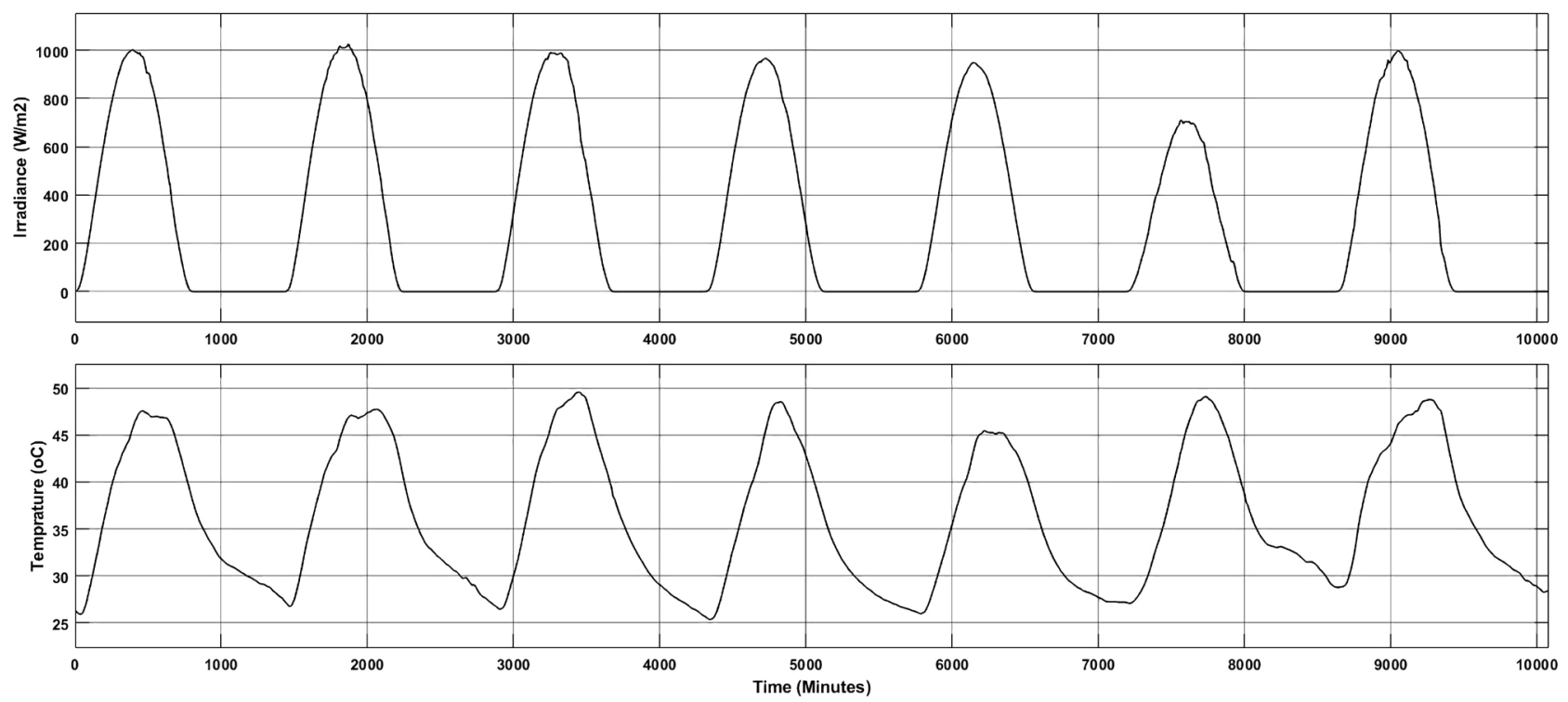

Figure 11. Irradiance and temperature during 1st week of April.
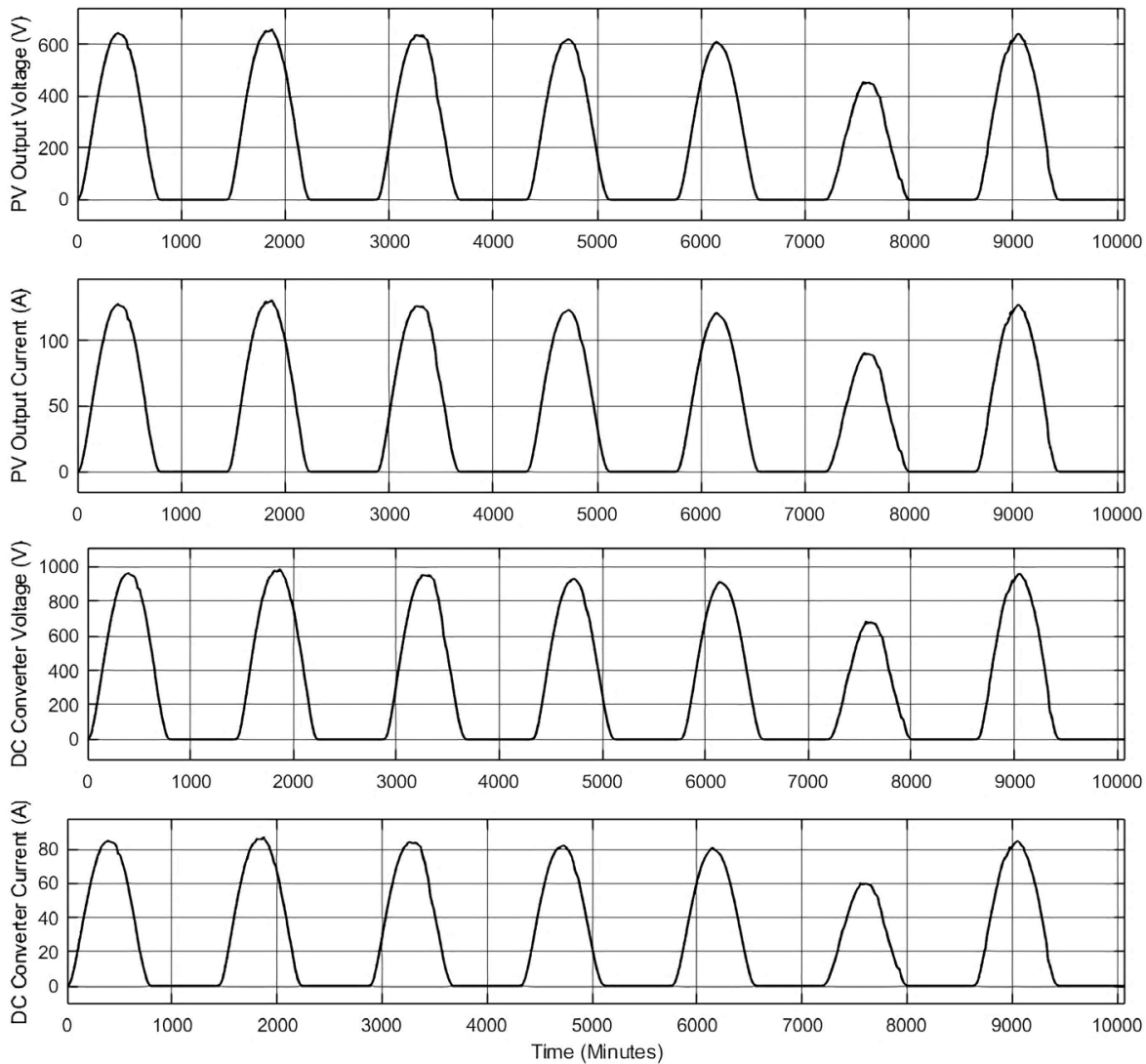

Figure 12. Simulation results for dynamic modeling; A.

$\mathrm{V}$ during 1st discharge but other than that it varied from $385.6 \mathrm{~V}$ to $379.5 \mathrm{~V}$. The momentarily pointed peak in battery voltage at the top as it reaches an SOC of $100 \%$ is because during the charging it takes into consideration the battery's internal resistance but once it stop charging since battery has reached $100 \%$ of 

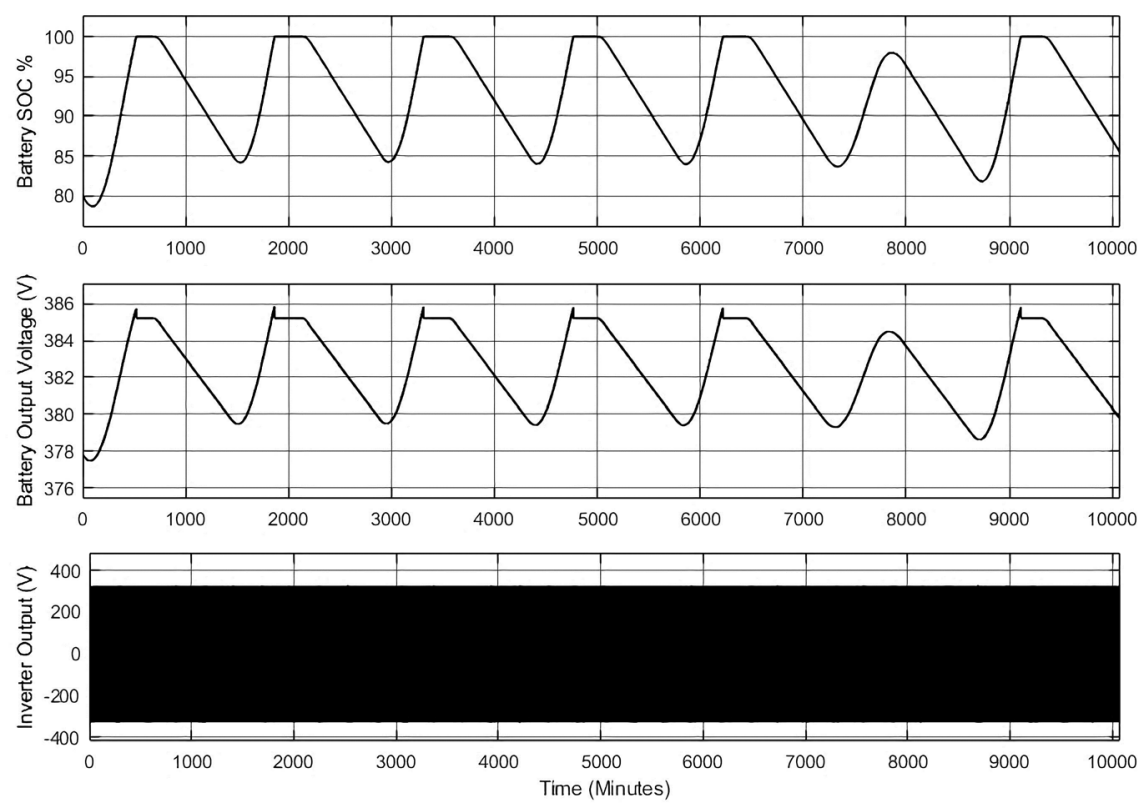

Figure 13. Simulation results for dynamic modeling; B.

SOC it no longer takes into consideration the battery's internal resistance hence, there is a slight decrease in overall battery's output voltage.

The voltage output of inverter varied from $+326.6 \mathrm{~V}$ to $-326.6 \mathrm{~V}$ peak as can be seen in Figure 13. In our system phase to neutral voltage is considered which is equal to $(400 / \sqrt{3}) * \sqrt{2}=326.6 \mathrm{~V}$. It is important to know that we have considered 4 wire three phase bridge inverter which can supply a voltage from phase to neutral and we have shown only one phase for inverter stage.

The detailed simulation results for the seven day simulation from April month of the motor/pump can be seen in Figure 14. It can be seen from the simulation results in figure that it took about 15 seconds to get to steady state and after that continuous operation of motor is at $1470 \mathrm{rpm}$ which is in accordance with the data sheet, also after the initial surge for $25 \mathrm{sec}$ which is the characteristic for induction motor the current stabilises from $326.6 \mathrm{~A}$ to $29.6 \mathrm{~A}$ within 15 seconds which is the current for phase to neutral current which is equal to $20.9 \mathrm{~A}$ (As per motor data sheet) $\times \sqrt{2}=29.6 \mathrm{~A}$.

\section{Design of Solar Water Pumping System with Water Tank in HOMER}

\subsection{Load Determination for the Proposed System}

Before proceeding with the design the first step was to determine an optimum size of a tank which could be large enough to keep a storage of water for 1 day. So for this flow rate for 1 day was calculated as can be seen below.

$$
204 \mathrm{~m}^{3} / \mathrm{hr} \times 24=4896 \mathrm{~m}^{3}
$$

So flow rate for one day is $4896 \mathrm{~m}^{3}$. Hence, if the motor runs for 5 hours each day during active days of the month (when continuous water flow is required). The flow rate required of the motor is $4896 / 5=979.2 \mathrm{~m}^{3} / \mathrm{hr}$. 

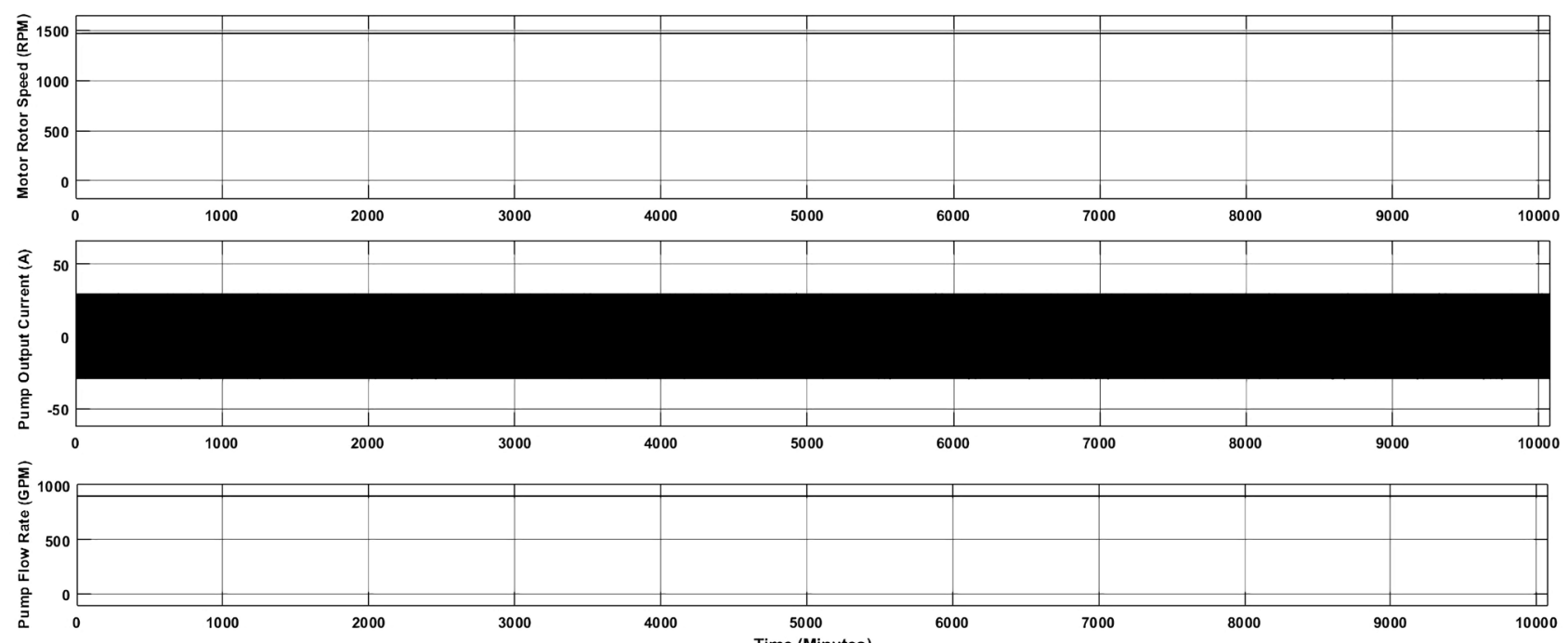

Figure 14. Simulation results for dynamic modeling of motor/pump.

Hence, using online source of Wilo pump [36] and using the previous know data regarding total dynamic head and calculated flow rate requirement, the size of the motor came out to be $55 \mathrm{~kW}$ and the motor selected for this purpose was CronoNorm-NLG 250/360-55/4 [41]. The details regarding the motor can be seen in Figure 15. The further details regarding the graph can be seen in Figure 16.

\subsection{Sizing of the Proposed System Using HOMER}

After the size of the motor was evaluated, the load was mapped in keeping the operational hours of the motor to be 5 hours. The load of the motor since is associated with a water tank storage so a deferrable load is used in HOMER and as the motor is running for 5 hours, so $55 \times 5=275 \mathrm{kWh}$ is the storage capacity required. The detailed load mapping in the deferrable load in HOMER can be seen in Figure 17.

The overall proposed system with water tank in HOMER appears as can be seen in the Figure 18. The PV panel used was Astronergy ASM6612P-320 solar [38] for design of PV panel network, the inverter used is SMA American STP60-US-10 [42] which is $60 \mathrm{~kW}$ inverter.

After the simulation of the overall proposed solar water pumping system was conducted; the requirement of the PV Panel network came out to be $72.3 \mathrm{~kW}$, the inverter requirement came out to be $59.9 \mathrm{~kW}$, which is fulfilled by $60 \mathrm{~kW}$ SMA American STP60-US-10. The overall result is seen in Figure 19.

The overall proposed system with water tank can be seen in Figure 20. To fulfill the requirement of $72.3 \mathrm{~kW}, 240$ panels were used, as the bus voltage is $360 \mathrm{~V}$.

\subsection{Cost Analysis of the Proposed System with Water Tank Using HOMER}

The overall cost summary for the proposed system was performed in HOMER 


\section{Operating data}

Fluid media: Water $100 \%$

Fluid temperature: $20.00{ }^{\circ} \mathrm{C}$

Fluid concentration: $100.00 \%$

Requested flow: $979.20 \mathrm{~m}^{3} / \mathrm{h}$

Requested head: $35.00 \mathrm{ft}$

Min. fluid temperature: $-20^{\circ} \mathrm{C}$

Max. fluid temperature: $120{ }^{\circ} \mathrm{C}$

Maximum operating pressure: 16 bar

Max. ambient temperature: $40^{\circ} \mathrm{C}$

Minimum efficiency index (MEI): $\geq 0.4$

\section{Motor data}

Mains connection: $3 \sim 400 \mathrm{~V} / 50 \mathrm{~Hz}$

Voltage tolerance: $\pm 10 \%$

Motor efficiency class: IE3

Rated power: $55 \mathrm{~kW}$

Rated speed: $14801 / \mathrm{min}$

Rated current: $98.6 \mathrm{~A}$

Power factor: 0.85

Motor efficiency: $0.0 \%$

Motor efficiency: $0.0 \%$

Motor efficiency: $0.0 \%$

Protection class:

Insulation class: $\mathrm{F}$

\section{Installation dimensions}

Pipe connection on the suction side: DN 300, PN16

Pipe connection on the pressure side: DN 250, PN16

Figure 15. Details of motor/pump selected.

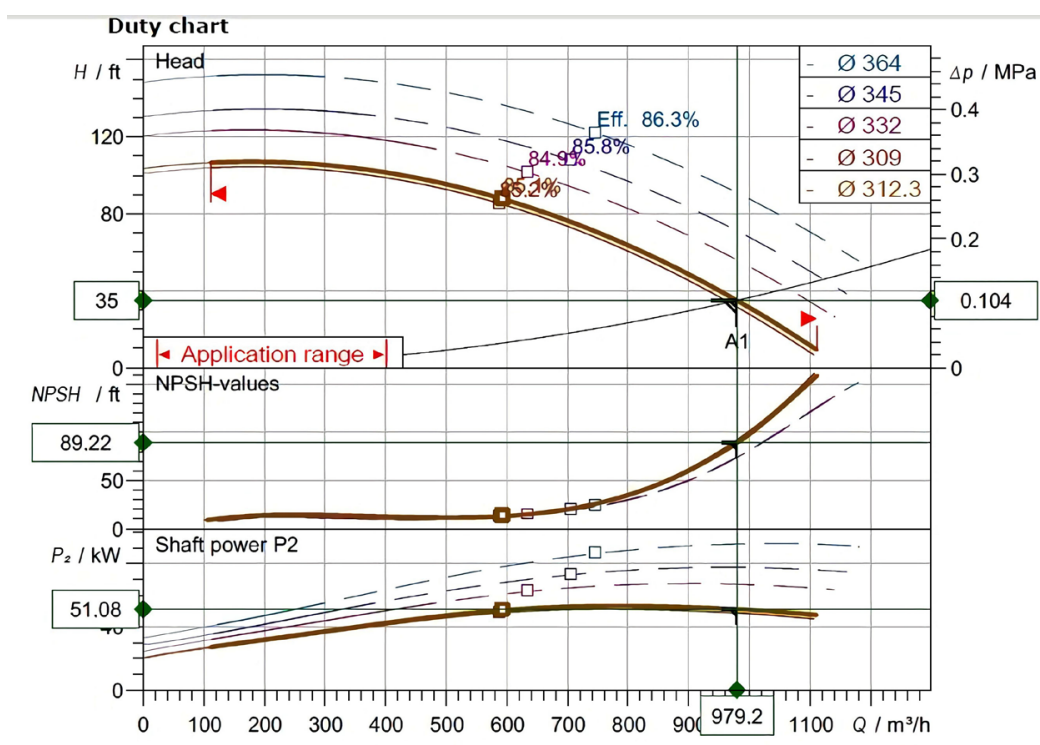

Figure 16. Parameters which led to the motor/pump selection.

$\begin{array}{ll}\text { Requested data } & \\ \text { Flow } & 979.20 \mathrm{~m}^{3} / \mathrm{h} \\ \text { Head } & 35.00 \mathrm{ft} \\ \text { Media } & \text { Water } 100 \% \\ \text { Fluid temperature } & 20.00^{\circ} \mathrm{C} \\ \text { Density } & 998.20 \mathrm{~kg} / \mathrm{m}^{3} \\ \text { Kin. viscosity } & 1.00 \mathrm{~mm} / \mathrm{s} \\ \text { Hydraulic data (Duty point) } & \\ \text { Flow } & 979.20 \mathrm{~m}^{3} / \mathrm{h} \\ \text { Head } & 35.00 \mathrm{ft} \\ \text { Shaft power P2 } & 51.08 \mathrm{~kW} \\ \text { Hydraulic efficiency } & 55.33 \% \\ \text { NPSH } & 89.22 \mathrm{ft} \\ \text { Impeller size } & 312.3 \\ \text { Product data } & \\ \text { Glanded standard pump } & \\ \text { NLG 250/360-55/4 } & \\ \text { Max. operating pressure } & 1.6 \mathrm{MPa} \\ \text { Fluid temperature } & -20^{\circ} \mathrm{C} \ldots+120^{\circ} \mathrm{C} \\ \text { Max. ambient temperature } & 40^{\circ} \mathrm{C} \\ \text { Minimum efficiency index (MEI) } & \geq 0.4 \\ \text { Motordata per Motor/Pump } & \\ \text { Motor efficiency level } & \text { IE3 } \\ \text { Mains connection } & 3 \sim 400 \mathrm{~V} / 50 \mathrm{~Hz} \\ \text { Permitted voltage tolerance } & \pm 10 \% \\ \text { Max. speed } & 14801 / \mathrm{min} \\ \text { Rated power P2 } & 55.00 \mathrm{~kW} \\ \text { Rated current } & 98.60 \mathrm{~A} \\ \text { Power factor } & 0.85 \\ & \end{array}$

Power factor 


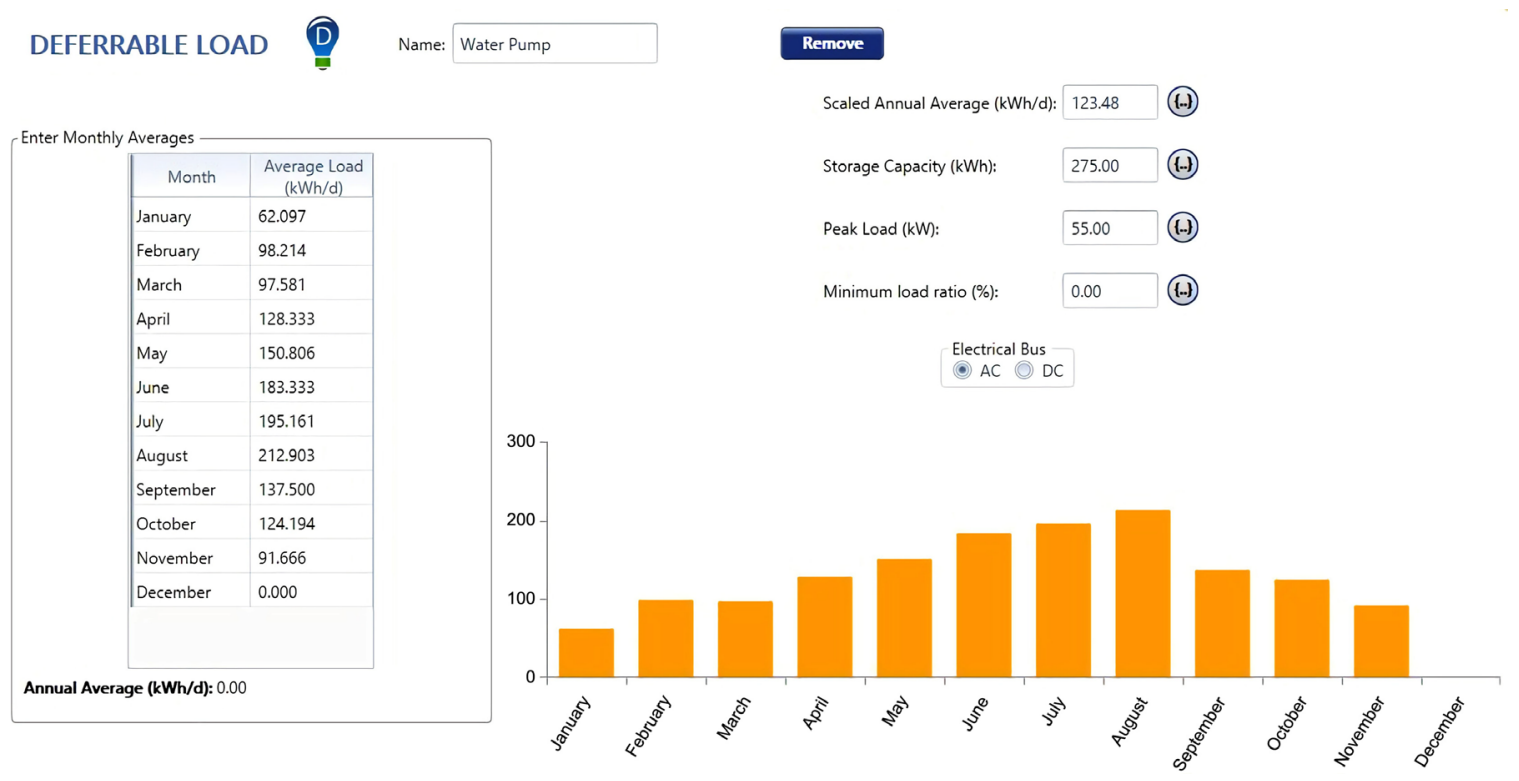

Figure 17. Load mapping in HOMER.

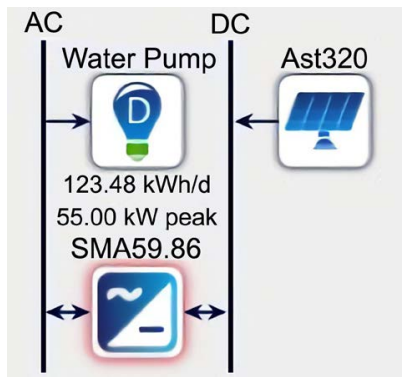

Figure 18. Proposed solar water pumping system with water tank.

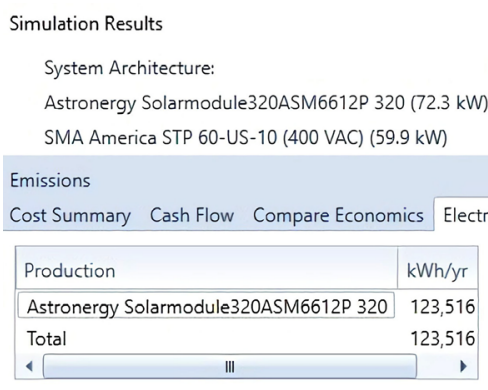

HOMER Cycle Charging

Cost Summary Cash Flow Compare Economics Electrical Renewable Penetration Astronergy Solarmodule320ASM6612P 320 SMA America STP 60-US-10 (400 VAC)

\begin{tabular}{|l|l|l|}
\hline Consumption & $\mathrm{kWh} / \mathrm{yr}$ & $\%$ \\
\hline AC Primary Load & 0 & 0 \\
DC Primary Load & 0 & 0 \\
Deferrable Load & 45,056 & 100 \\
Total & 45,056 & 100 \\
\hline
\end{tabular}

\begin{tabular}{|l|l|l|}
\hline Quantity & $\mathrm{kWh} / \mathrm{yr}$ & $\%$ \\
\hline Excess Electricity & 77,541 & 62.8 \\
Unmet Electric Load & 44.3 & 0.0982 \\
Capacity Shortage & 44.3 & 0.0982 \\
\hline
\end{tabular}

\begin{tabular}{|l|l|l|}
\hline Quantity & Value & Units \\
\hline Renewable Fraction & 100 & $\%$ \\
Max. Renew. Penetration & 2.573 & $\%$ \\
\hline
\end{tabular}

Max. Renew. Penetration $2,573 \%$

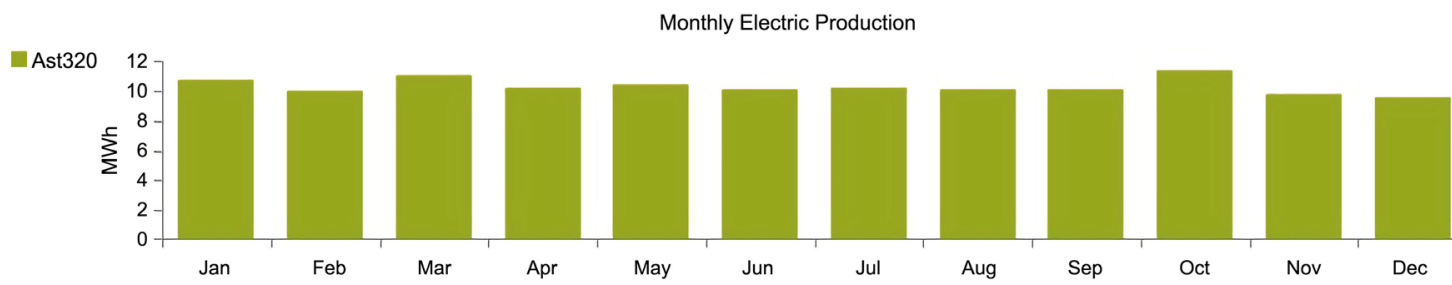

Figure 19. Simulation details for proposed system with water tank. 


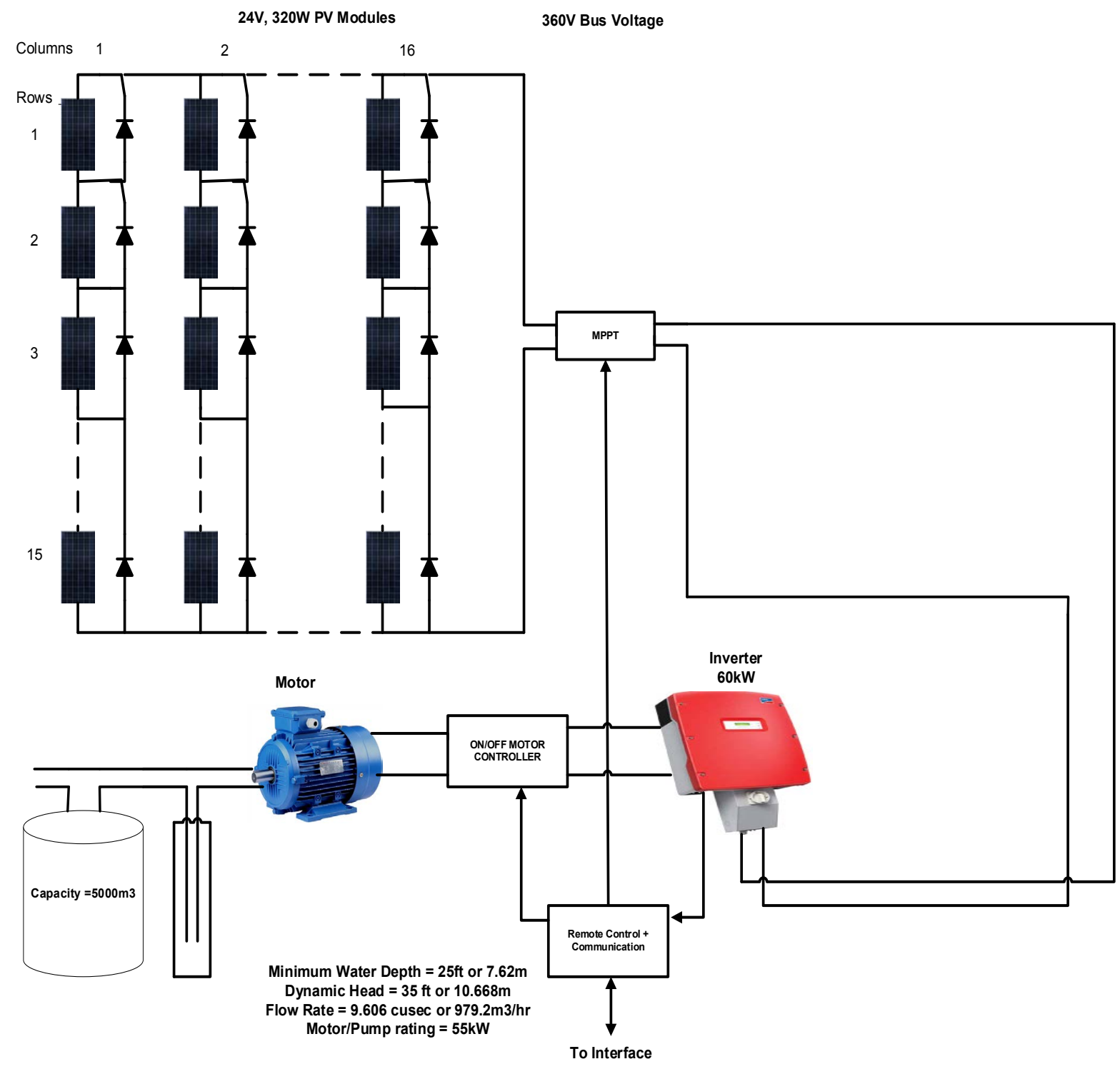

Figure 20. Proposed solar water pumping system with water tank.

and the result can be seen in Figure 21. The total net present cost of the proposed system came out to be $\$ 103,858.30$, levelized cost of energy is $\$ 0.1783$ and operating cost of the proposed system is $\$ 4649.93$ per year.

The cash flow for the proposed system over the 25 years of life time can be seen in Figure 22. It can be seen that an initial investment of $\$ 43,746.27$ is required, than an annual investment of $\$ 4520.83$ is required to keep the system running. Then a further funds injection of $\$ 4845.41$ in 15th year of 25 years project life is required. After the end of 25 years of project life cycle, a salvage value of $\$ 1615.14$ is available.

\subsection{Sizing of Water Tank}

As the total water discharge in one day is $4896 \mathrm{~m}^{3}$, so a tank of $5000 \mathrm{~m}^{3}$ is planned. For this the mathematical details are as follows. 
System Architecture:

HOMER Cycle Charging

Total NPC:

$\$ 103,858.30$

Astronergy Solarmodule320ASM6612P 320 (72.3 kW)

Levelized COE:

$\$ 0.1783$

SMA America STP 60-US-10 (400 VAC) $(59.9 \mathrm{~kW})$

Emissions

Cost Summary Cash Flow Compare Economics Electrical Renewable Penetration Astronergy Solarmodule320ASM6612P 320 SMA America STP 60-US-10 (400 VAC)
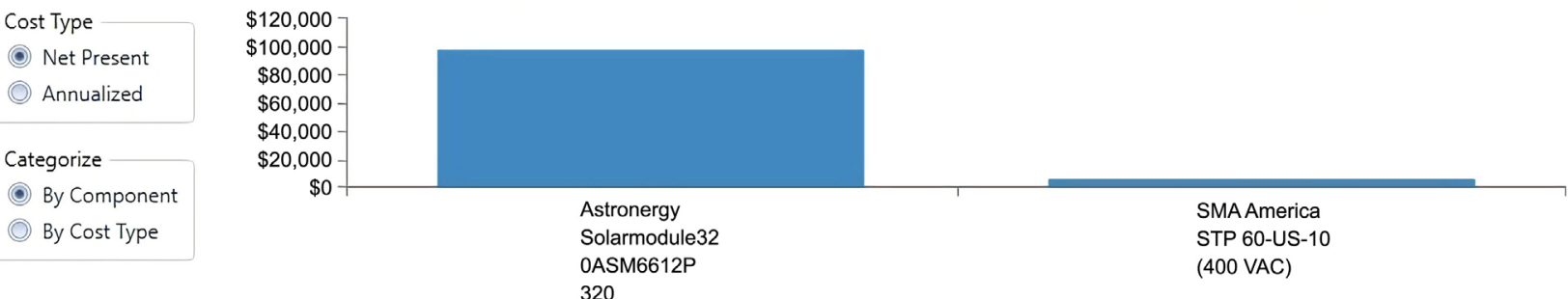

\begin{tabular}{|l|r|r|r|rr|r|}
\hline Component & Capital (\$) & Replacement (\$) & O\&M (\$) & Fuel (\$) & Salvage (\$) & Total (\$) \\
\hline Astronergy Solarmodule320ASM6612P 320 & $\$ 38,900.87$ & $\$ 0.00$ & $\$ 58,443.15$ & $\$ 0.00$ & $\$ 0.00$ & $\$ 97,344.01$ \\
SMA America STP 60-US-10 (400 VAC) & $\$ 4,845.41$ & $\$ 2,055.78$ & $\$ 0.00$ & $\$ 0.00$ & $(\$ 386.92)$ & $\$ 6,514.27$ \\
System & $\$ 43,746.27$ & $\$ 2,055.78$ & $\$ 58,443.15$ & $\$ 0.00$ & $(\$ 386.92)$ & $\$ 103,858.28$ \\
\hline
\end{tabular}

Figure 21. Cash summary for proposed system without battery.

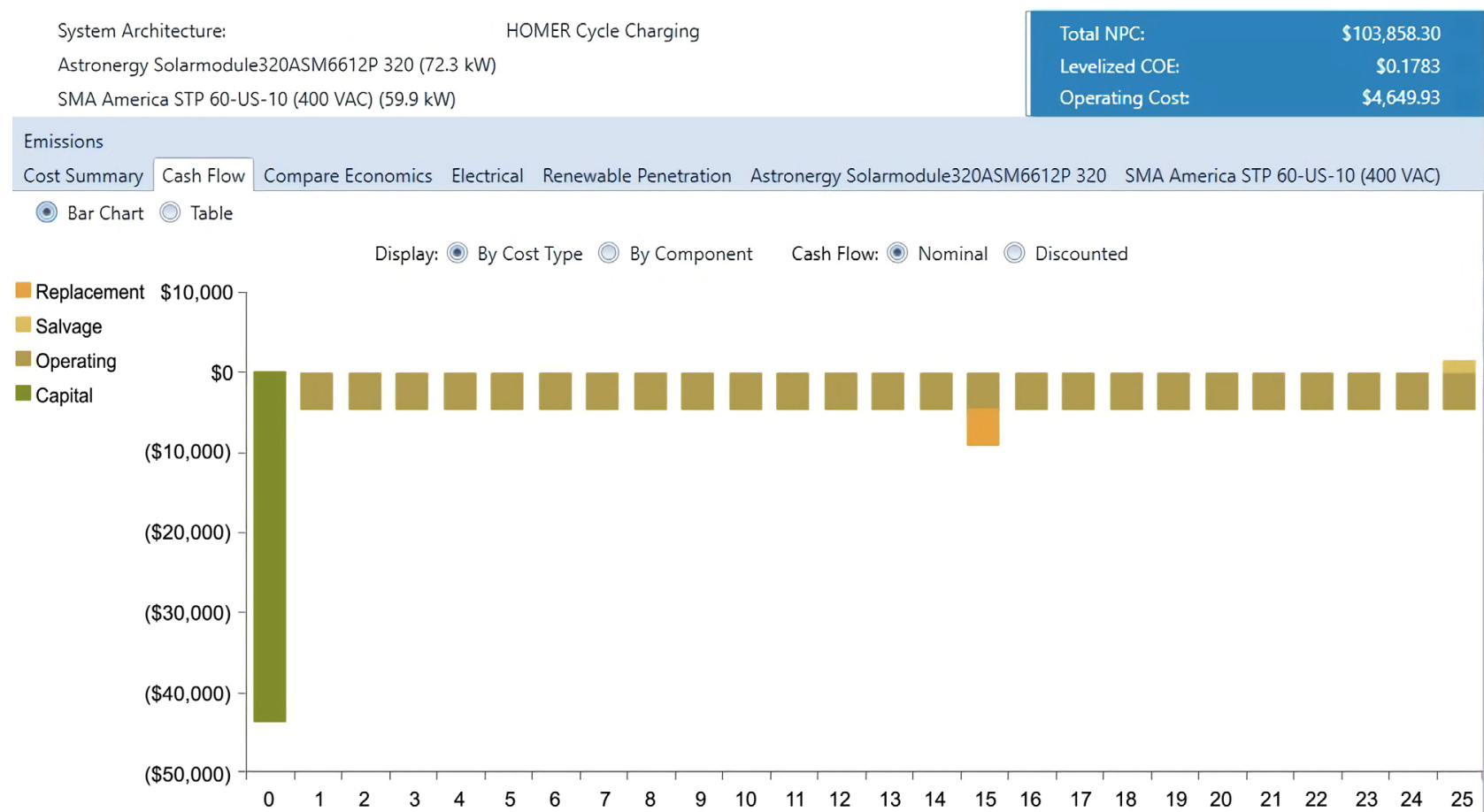

Figure 22. Cash flow for proposed system without battery.

Considering a cylindrical tank of $5000 \mathrm{~m}^{3}$ with a height of $2 \mathrm{~m}$. The radius of the tank can be calculated using Equation (1).

$$
V=\pi r^{2} h
$$

Here $V$ is for volume in $\mathrm{m}^{3} ; r$ is radius of the cylinder in meters; $h$ is the height 
of the tank in meter

$$
5000=3.142 \times r^{2} \times 2
$$

$\mathrm{r}=28.21 \mathrm{~m}$

Hence, the radius of the tank is $28.21 \mathrm{~m}$.

\section{Costing of the Water Tank}

Local rate for construction including material, labour, digging and supervision lumped together costs Rs $300 / \mathrm{ft}^{2}$.

As the tank is open from top, so the total surface area can be calculated using Equation (2).

$$
\text { Surface Area }=\pi r^{2}+2 \pi r h
$$

Surface area $=3.142 \times 28.212+2 \times 3.142 \times 28.21 \times 2$

Surface area $=2854.6 \mathrm{~m}^{2}=30726.6587 \mathrm{ft}^{2}$

Overall price for tank is $30,727 \times 300=$ Rs $92,181.00=\$ 54,540.88$

\section{Conclusions}

A detailed sizing and economic analysis of solar system with battery bank was performed using HOMER software to evaluate the steady state analysis of system. It was found out that $73.8 \mathrm{~kW}$ of PV panel network, 450 batteries of Trojan SAGM 12105 and $16.7 \mathrm{~kW}$ of inverter are required to realise a system for a motor load of $11 \mathrm{~kW}$. To further study the system, dynamic analysis of the proposed system was done in MATLAB/Simulink. Mathematical modeling of PV panel, battery bank, inverter, buck-boost converter and selected model and pump along with a control system was done to represent the overall system in shape of maximum power point tracking by Perturb and observe algorithm that was used to control the duty cycle. This helped to further validate the designed solar water pumping system in HOMER.

A detailed sizing of another option was also proposed for the selected agricultural site which was supported by a cylindrical water tank instead of a battery bank. For this system, the PV panel network requirement came out to be 72.3 $\mathrm{kW}$, the inverter requirement came out to be $59.9 \mathrm{~kW}$ and this all was required for the motor of load $55 \mathrm{~kW}$ and the water tank volume requirement came out to be $4896 \mathrm{~m}^{3}$.

\section{Economics Comparison of Two Designed Solar Water Pumping Systems}

To compare the solar water pumping systems design their economic analysis is considered, which was also performed using HOMER software. It can be seen in the results that overall net present cost of the system with battery bank was $\$ 273,570$ and the net present cost for the system with water tank came out to be $103,858.3+54,540.88=\$ 158,399$. Levelized cost for the system with battery was $\$ 0.48$ and levelized cost for the system with water tank was $\$ 0.1783$. Hence, 
keeping in view the net present costs and levelized costs of the systems, the PV system with water tank can safely be regarded as a better option. Operating costs per year are $\$ 5692.37$ and $\$ 4649.93$ for systems with battery and without battery respectively which again goes in favour of system without battery. Last parameter is initial investments which are $\$ 199,981.86$ and $43,746.27+54,580.88=$ $\$ 98,327.15$ for systems with battery and without battery respectively which again goes in favour of system without battery. This factor is less as compared to battery based system, because construction of tank is relatively cheaper in Pakistan due to availability of cheap labour.

Hence, it can be concluded that solar water pumping system based on water tank is cheaper as compared to solar water pumping system based on battery.

\section{Acknowledgements}

We specially like to thank Mr. Aslam Yusuf (Advisor Technical Services) of Farm Dynamics Pakistan (Pvt) Ltd. and Mr. Tahir Mushtaq serving as manager Mustafa Research Farm for providing us with necessary site details which were very helpful while writing this paper. At the end, thanks to NSERC for funding this research.

\section{Conflicts of Interest}

The authors declare no conflicts of interest regarding the publication of this paper.

\section{References}

[1] Adnan, M., et al. (2020) Variability and Predictability of Summer Monsoon Rainfall over Pakistan. Asia-Pacific Journal of Atmospheric Sciences. https://doi.org/10.1007/s13143-020-00178-2

[2] Nabi, G., Ali, M., Khan, S. and Kumar, S. (2019) The Crisis of Water Shortage and Pollution in Pakistan: Risk to Public Health, Biodiversity, and Ecosystem. Environmental Science and Pollution Research, 26, 10443-10445. https://doi.org/10.1007/s11356-019-04483-w

[3] Khan, A. and Awan, N. (2020) Inter-Provincial Water Conflicts in Pakistan: A Critical Analysis. Journal of South Asian and Middle Eastern Studies, 43, 42-53.

[4] Ahmad, B. (2011) Water Management: A Solution to Water Scarcity in Pakistan. Journal Independent Studies and Research, 9, 111-125. https://doi.org/10.31384/jisrmsse/2011.09.2.9

[5] Rafique, M.M. and Rehman, S. (2017) National Energy Scenario of Pakistan-Current Status, Future Alternatives, and Institutional Infrastructure: An Overview. Renewable and Sustainable Energy Reviews, 69, 156-167. https://doi.org/10.1016/j.rser.2016.11.057

[6] Shahid, M., Ullah, K., Imran, K., Mahmood, I. and Mahmood, A. (2020) Electricity Supply Pathways Based on Renewable Resources: A Sustainable Energy Future for Pakistan. Journal of Cleaner Production, 263, Article ID: 121511. https://doi.org/10.1016/j.jclepro.2020.121511

[7] Muhammad, F., Waleed Raza, M., Khan, S. and Khan, F. (2017) Different Solar Potential Co-Ordinates of Pakistan. Innovative Energy \& Research, 6, 173. 
https://doi.org/10.4172/2576-1463.1000173

[8] Choudhary, P., Srivatava, R.K. and De, S. (2017) Solar Powered Induction Motor Based Water Pumping System: A Review of Components, Parameters and Control Methodologies. 2017 4th IEEE Uttar Pradesh Section International Conference on Electrical, Computer and Electronics (UPCON), Mathura, October 2017, 666-678. https://doi.org/10.1109/UPCON.2017.8251129

[9] Lund, H., Sorknæs, P., Mathiesen, B.V. and Hansen, K. (2018) Beyond Sensitivity Analysis: A Methodology to Handle Fuel and Electricity Prices When Designing Energy Scenarios. Energy Research \& Social Science, 39, 108-116. https://doi.org/10.1016/j.erss.2017.11.013

[10] Allouhi, A., et al. (2019) PV Water Pumping Systems for Domestic Uses in Remote Areas: Sizing Process, Simulation and Economic Evaluation. Renewable Energy, 132, 798-812. https://doi.org/10.1016/j.renene.2018.08.019

[11] Sharma, V.K., Colangelo, A. and Spagna, G. (1995) Photovoltaic Technology: Basic Concepts, Sizing of a Stand Alone Photovoltaic System for Domestic Applications and Preliminary Economic Analysis. Energy Conversion and Management, 36, 161-174. https://www.sciencedirect.com/science/article/abs/pii/0196890494000658

[12] Egido, M. and Lorenzo, E. (1992) The Sizing of Stand Alone PV-System: A Review and a Proposed New Method. Solar Energy Materials \& Solar Cells, 26, 51-69. https://doi.org/10.1016/0927-0248(92)90125-9

[13] Markvart, T., Fragaki, A. and Ross, J.N. (2006) PV System Sizing Using Observed Time Series of Solar Radiation. Solar Energy, 80, 46-50. https://doi.org/10.1016/j.solener.2005.08.011

[14] Rawat, R., Kaushik, S.C. and Lamba, R. (2016) A Review on Modeling, Design Methodology and Size Optimization of Photovoltaic Based Water Pumping, Standalone and Grid Connected System. Renewable and Sustainable Energy Reviews, 57, 1506-1519. https://doi.org/10.1016/j.rser.2015.12.228

[15] Kumar, N.M. (2017) Simulation Tools for Technical Sizing and Analysis of Solar PV Systems. Proceedings of the 6 th World Conference on Applied Sciences, Engineering and Technology (WCSET-2017), 26-27 August 2017, 218-222.

[16] Canada, N.R. (2010) RETScreen.

https://www.nrcan.gc.ca/maps-tools-publications/tools/data-analysis-software-mod elling/retscreen/7465

[17] Solargis:: pvPlanner. https://solargis.info/pvplanner/\#tl=Google:hybrid\&bm=satellite

[18] Home. PVsyst. https://www.pvsyst.com

[19] Solar Pro PV Simulation and Design. Laplace Systems. http://www.laplacesolar.com/photovoltaic-products/solar-pro-pv-simulation-design

[20] Home-System Advisor Model (SAM). https://sam.nrel.gov

[21] Homer Pro Microgrid Software for Designing Optimized Hybrid Microgrids. https://www.homerenergy.com/products/pro/index.html

[22] Welcome TRNSYS: Transient System Simulation Tool. http://www.trnsys.com

[23] What Is LabVIEW?" https://www.ni.com/en-ca/shop/labview.html

[24] MATLAB-MathWorks. https://www.mathworks.com/products/matlab.html

[25] Chaichan, M.T., Kazem, A.H.A., El-Din, M.M.K., Al-Kabi, A.H.K., Al-Mamari, A.M. and Kazem, H.A. (2017) Optimum Design and Evaluation of Solar Water Pumping System for Rural Areas. International Journal of Renewable Energy Research, 7, Art. No. 1. 
[26] Kazem, H.A., Al-Waeli, A.H.A., Chaichan, M.T., Al-Mamari, A.S. and Al-Kabi, A.H. (2017) Design, Measurement and Evaluation of Photovoltaic Pumping System for Rural Areas in Oman. Environment, Development and Sustainability, 19, 1041-1053. https://doi.org/10.1007/s10668-016-9773-Z

[27] Chaichan, M.T., Kazem, H.A., Mahdy, A.M.J. and Al-Waeely, A.A. (2016) Optimal Sizing of a Hybrid System of Renewable Energy for Lighting Street in Salalah-Oman Using Homer Software. International Journal of Scientific Engineering and Applied Science, 2, 157-164.

[28] Kammash, K. (2019) IJOCAAS-01-02-001-Oct2016. International Journal of Computation and Applied Sciences, 1, 1.

[29] Alkarrami, F., Iqbal, T. and Pope, K. (2016) Optimal Sizing of a Stand-Alone Hybrid Energy System for Water Pumping in Sirte, Libya. 2016 IEEE Electrical Power and Energy Conference (EPEC), Ottawa, October 2016, 1-5.

https://doi.org/10.1109/EPEC.2016.7771679

[30] Biswas, S. and Iqbal, T. (2018) Dynamic Modelling of a Solar Water Pumping System with Energy Storage. Journal of Solar Energy, 2018, Article ID: 8471715. https://doi.org/10.1155/2018/8471715

[31] Alkarrami, F., Iqbal, T., Pope, K. and Rideout, G. (2020) Dynamic Modelling of Submersible Pump Based Solar Water-Pumping System with Three-Phase Induction Motor Using MATLAB. Journal of Power and Energy Engineering, 8, 20-64. https://doi.org/10.4236/jpee.2020.82002

[32] Kumar, R. and Singh, B. (2016) BLDC Motor-Driven Solar PV Array-Fed Water Pumping System Employing Zeta Converter. IEEE Transactions on Industry Applications, 52, 2315-2322. https://doi.org/10.1109/TIA.2016.2522943

[33] Murshid, S. and Singh, B. (2019) Implementation of PMSM Drive for a Solar Water Pumping System. IEEE Transactions on Industry Applications, 55, 4956-4964. https://doi.org/10.1109/TIA.2019.2924401

[34] $28^{\circ} 14^{\prime} 24.0^{\prime \prime} \mathrm{N} 69^{\circ} 37^{\prime} 16.0^{\prime \prime} \mathrm{E} .28^{\circ} 14^{\prime} 24.0^{\prime \prime} \mathrm{N} 69^{\circ} 37^{\prime} 16.0^{\prime \prime} \mathrm{E}$. https://www.google.com/maps/place/28\%C2\%B014'24.0\%22N+69\%C2\%B037'16.0\% 22E/@28.2412729,69.6187179,2035m/data $=! 3 \mathrm{~m} 1 ! 1 \mathrm{e} 3 ! 4 \mathrm{~m} 5 ! 3 \mathrm{~m} 4 ! 1 \mathrm{~s} 0 \times 0: 0 \times 0 ! 8 \mathrm{~m} 2 ! 3 \mathrm{~d} 28$ $.24 ! 4 \mathrm{~d} 69.6211111$

[35] National Renewable Energy Laboratory (NREL) Home Page. https://www.nrel.gov/index.html

[36] Wilo-Select 4. https://wilo-select.com/Region.aspx

[37] Atmos GIGA-N 125/200-11/4. https://wilo.com/lb/en/Products-and-expertise/Series-Finder/Atmos-GIGA-N-125200-11-4_11817.html

[38] Astronergy 320 Watt Solar Panel-Made in Germany-ASM6612P-320 Wp. https://www.ecodirect.com/product-p/astronergy-asm6612p-320-wp.htm

[39] Trojan SAGM 12 105. Battery Heaven \& Solar Solutions. https://www.batteryheavenpr.com/products/trojan-sagm-12-105

[40] SMA Sunny Tripower 20000TL-30. SMA STP 20000TL-30 Inverter. Europe Solar Store. https://www.europe-solarstore.com/sma-sunny-tripower-20000tl-30.html

[41] CronoNorm-NLG 250/360-55/4. https://wilo.com/lb/en/Products-and-expertise/Series-Finder/CronoNorm-NLG-25 0-360-55-4_232.html

[42] SMA Sunny Tripower 60. SMA STP 60-10 Solar Inverter. Europe Solar Store. https://www.europe-solarstore.com/sma-sunny-tripower-60.html 